\title{
MUSCLE, NERVE, AND SYNOVIAL CHANGES IN LUPUS ERYTHEMATOSUS*
}

\author{
BY \\ EDWARD W. LOWMAN \\ Rochester, Minn., U.S.A.
}

In disseminated lupus erythematosus synovial and muscle manifestations are prominent clinical features, but only meagre histopathological studies of these tissues have been made in this disease. We have undertaken, therefore, to investigate pathological changes in the striated muscle, peripheral nerves, and synovia of patients dying of lupus erythematosus.

\section{Method}

All material used was autopsy material. Lupus erythematosus was in all cases the primary cause of death. Muscle was available in fifteen cases, peripheral nerves in fifteen, and synovia in five. The tissue was embedded in paraffin blocks and serially sectioned. A minimum of 300 serial sections were cut from each block, and every tenth section was mounted and stained for study.

As controls, muscles and nerves were obtained from thirty other autopsies and prepared in a manner identical to the above. In addition, material from ten cases of rheumatoid arthritis was obtained and similarly studied. These latter findings are being more fully reported elsewhere.

\section{Findings}

The prominent changes which have been noted are muscle degeneration, and venous changes consisting of three phases: oedema, reaction, and sclerosis.

Muscle degeneration in the cases of lupus occurred much more frequently than in the control group. It was usually of slight to moderate extent and rarely generalized. It appeared focally or in a disseminated pattern. It was not possible to correlate focal muscle degeneration with focal vascular changes, although they were never completely dissociated. The degeneration varied from early loss of striations to old falling out of muscle tissue with fibrotic replacement. The changes varied from muscle to muscle in the same patient.

The vascular involvement in the muscle and nerve tissue from lupus cases was widespread and characteristic. It was typically venous in location with only occasional involvement of the arterial side of the system. It appeared that the initial phase was an acute oedematous phlebitis in which the vein wall was markedly thickened and hydropic in appearance and the cells of the wall swollen. This seemed to progress to a secondary reactive phase in which the vein wall underwent a reactive reparative process as evidenced by the presence of many cells both within

* Read at the Annual Meeting of the American Rheumatism Association, San Francisco, Calif. June, 1950. 
and about the vessel wall. The early reactive lesion showed a central zone of large mononuclear cells having vesicular nuclei, and an outer zone of lymphocytes in a ratio of about $1: 1$. Fibroblasts were evident early, and occasional plasma cells and an infrequent eosinophil were seen peripherally. In the older reactive lesions the mononuclear cells were less numerous or absent, as were also fibroblasts, and there was then left a collar of lymphocytes within and about a condensed, thickened vein wall. In serial sections it was seen that this peri-vascular reaction was nodular in character, involving segments of the length of the vessel rather than its entire extent, the intervening uninvolved portions of the veins being of normal appearance. In the third or sclerotic phase, the cell aggregates were gone and there remained varying degrees of sclerotic thickening of the vein wall. It is not necessarily assumed that the reactive phase is essential for production of the sclerotic phase, particularly in view of the thesis of Klemperer and others (1941) that a variation in the tempo and intensity of injury may directly bring about sclerosis.

The vascular pattern of reaction noted in these lupus sections is identical with that found by us in some active cases of rheumatoid arthritis. It is similar to the reaction found in periarteritis nodosa, except that the latter predominantly involves the arterial side of the circulation with a venous overflow, the reverse of the involvement noted above. In this investigation of muscle and nerve changes, synovia from five cases of lupus were obtained and similarly studied by serial sections. In these synovia, the vascular changes were identical with those noted in the muscles and nerve sections, but in addition, the CT stroma was involved early with diffuse swelling. With progression of the vasculitis to the cellular reactive stage there was a stromal fibroblastic response and numerous young fibroblasts appeared. Ultimately, with subsidence of the process, the stroma returned to normal or residual sclerosis of vessels and fibrotic thickening of the CT stroma remained. The synovial-lining cells were little affected.

Muscle degeneration was noted in eleven (73 per cent.) of the fifteen lupus cases (Fig. 1), as contrasted with 37 per cent. of the thirty controls. The muscle degeneration in the

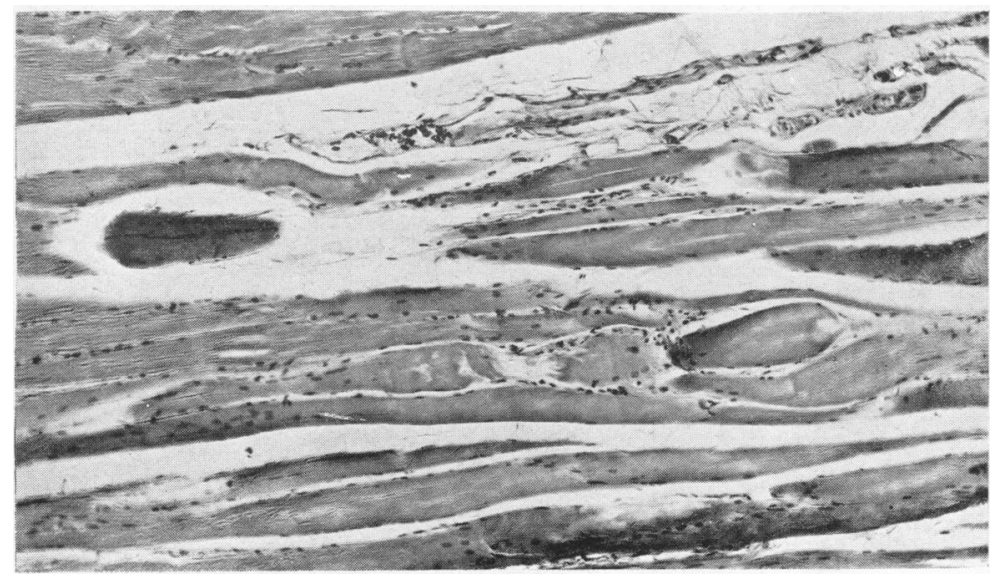

Fig. 1.-Focal muscle degeneration in lupus erythematosus. $\times 85$. 
control cases could usually be accounted for by the fatal disease processes. Clawson and others (1947) found from a study of 450 consecutive autopsy cases that atrophy of Grade 1 or more was present in one or more muscles in 42.4 per cent. of cases; our incidence of 37 per cent. in this control series is thus in keeping with his figures.

Perivascular cell aggregates were present in the muscle in every case of lupus and in only four (13 per cent.) of the control cases. In the nerves studied serially from the fifteen lupus cases, perivascular cell aggregates were present in fourteen ( 93 per cent.), only one case showing no aggregates in any nerve section. Of the thirty control cases, only three (10 per cent.) showed such aggregates.

Arterial changes were only occasionally seen in the lupus cases, and arteritis was never seen without co-existing phlebitis. In the control group arterial changes were present in 27 per cent. and could be accounted for by underlying disease processes.

Veins prominently showed the oedematous phase of phlebitis in the muscles of two lupus cases (Fig. 2), and in occasional nerve sections. The reactive phase with its associated perivascular aggregation of cells was prominent in muscle in every case of lupus and in nerve sections from 93 per cent. (Fig. 3). The sclerotic stage of phlebitis was apparent in muscle from 46 per cent. and in nerve tissue from 73 per cent. (Fig. 4, opposite).

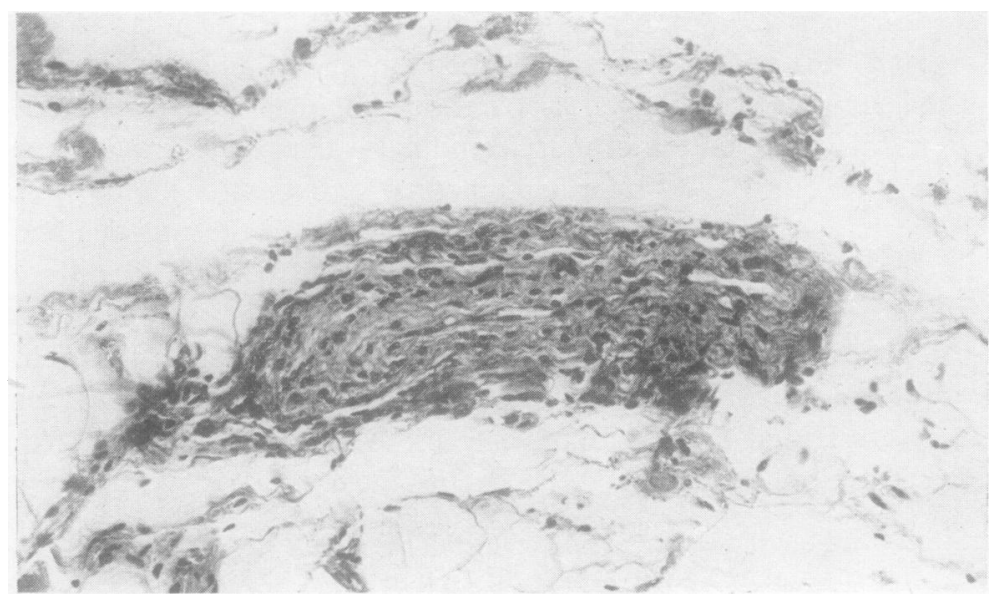

Fig.2.-Oedema and thickening of a vein wall with the beginning of cellular reaction. $\times 235$.

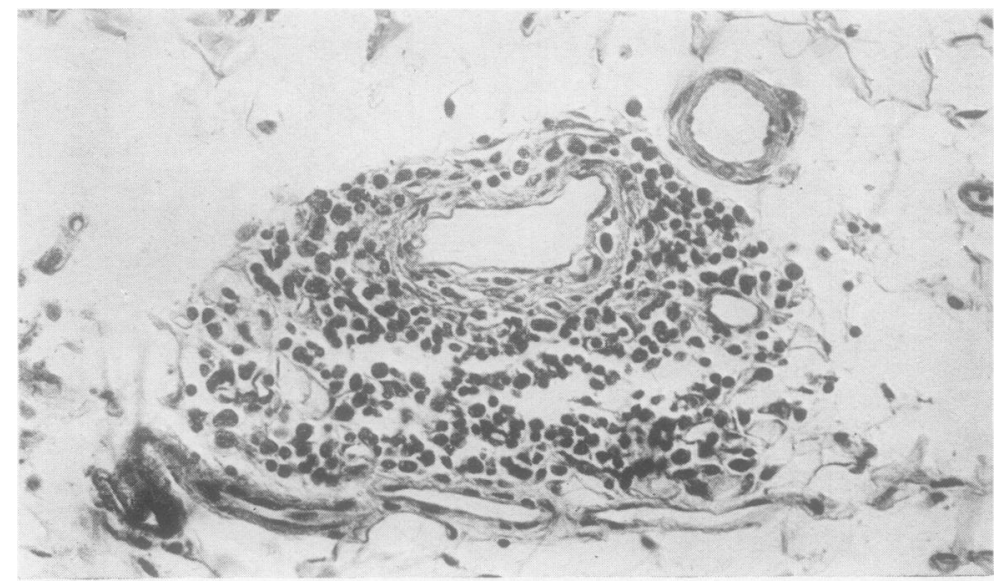

Fig. 3.-Venous and paravenous cellular reaction, reactive phase. $\times 235$. 


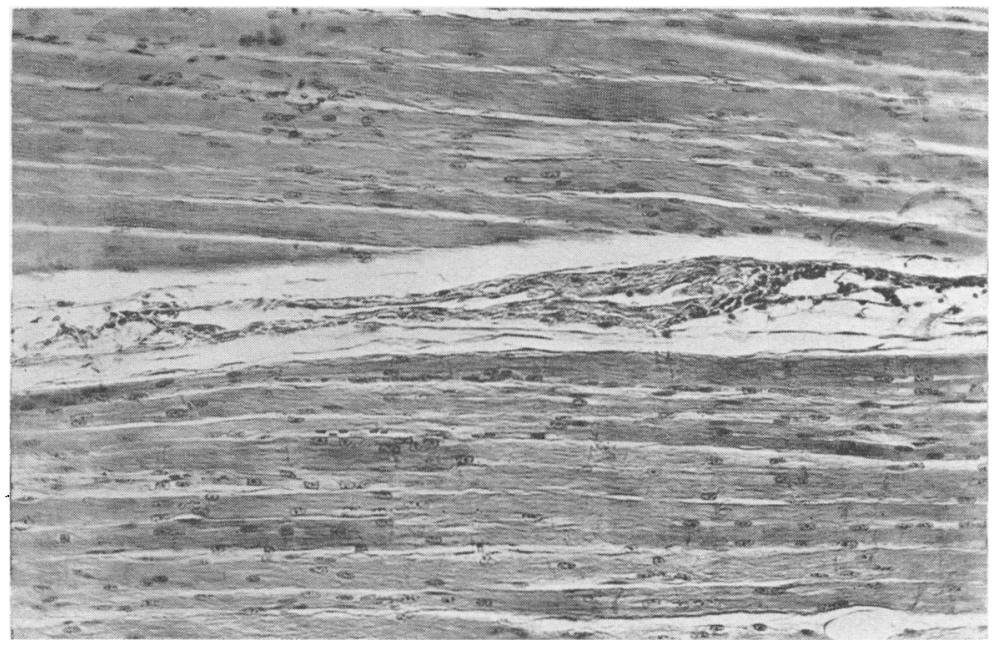

Fig. 4.-Sclerotic, or healed, stage of phlebitis. $\times 140$.

In only one muscle section from one case of lupus was there material suggesting fibrinoid degeneration and no instances of endothelial proliferation were noted.

Definite nerve degeneration of slight to moderate degree was noted in 53 per cent. of the fifteen lupus cases and in 37 per cent. of the thirty control cases.

The volume incidence of perivascular cell aggregates in the reactive phase of phlebitis is of interest. An average of $4 \cdot 1$ muscles were studied in each case of lupus; of the total of 62 muscles from the fifteen cases, 35 (56.4 per cent.) showed perivascular cell aggregates. Of the 27 nerves from the fifteen cases of lupus, 21 showed similar aggregates. Among the thirty controls, only five of 240 muscle specimens $(2 \cdot 1$ per cent.) and three of 110 nerve specimens $(2 \cdot 7$ per cent.) showed positive findings.

\section{Summary}

(1) In serially sectioned muscles from fifteen cases of lupus, slight to moderate muscle degeneration was noted in 73 per cent.; 37 per cent. of thirty control cases showed similar changes.

(2) In lupus erythematosus a vascular pattern of reaction on the venous side of the circulation appears to consist of three phases: oedema, cellular reaction, and sclerosis. These muscle and perineural vascular changes of lupus are identical with those seen by us in some active cases of rheumatoid arthritis. Muscle and nerve degeneration and vascular change could not be correlated in degree and it cannot be decided whether the one is the cause or consequence of the other, or whether they are simultaneous concomitant responses to a common stimulus. Synovial tissue showed vascular changes identical with the pattern of reaction seen elsewhere. In addition, the stroma showed initial oedema and subsequent fibroblastic response with ultimate resolution or fibrosis. Synovial-lining cells showed only occasional hyperplastic changes.

(3) The identical nature of the vascular reaction in lupus with that noted in cases of active rheumatoid arthritis, and the similarity of the reaction to that seen in periarteritis nodosa is of speculative interest for further investigation. 
(4) It could not be ascertained whether the reaction pattern is secondary to damage by an extraneous factor, or whether a hyperergic response is causing injury to the responding system.

\section{Discussion}

DR. JAMES W. Kernohan (Rochester, Minn.): I was much interested in the fact that the lesions are found in the veins rather than in the arteries. Regarding changes in lupus erythematosus and their relationship to other changes, Goeckerman (1923) pointed out that lupus erythematosus was not confined to the manifestation on the skin, but was also a systemic disease. Libman and Sacks (1924) showed valvular lesions in the heart, and Klemperer and others (1941) showed lesions in the kidneys. Now Dr. Lowman has shown changes in the muscles, nerves, vessels, and synovia; this also points to the fact that lupus erythematosus is a systemic disease affecting practically all the tissues in the body rather than one affecting only the skin.

I am still not sure why the changes occur in the muscles, whether they result from the degeneration of nerves or from action through the vascular system. I rather incline to the idea that they occur first in the vessels. It is true that Dr. Lowman was unable to find vascular changes in association with changes in the muscle in every case, but I still think the primary lesion is that in the walls of the blood vessels.

DR. J. J. BUNIM (New York): Dr. Lowman is to be congratulated for this very careful study in a rather difficult and controversial field. We were unable to find any changes on the venous side of the circulation in the skeletal muscle sections of patients with rheumatoid arthritis.* I noticed that Dr. Lowman was unable to find arterial changes in the muscles. Incidentally, I must emphasize that, like Dr. Lowman, we were dealing with changes in skeletal muscle, and not in the viscera.

I should like to ask whether Dr. Lowman considers the perivascular infiltration round the veins as diagnostic of lupus erythematosus. So often biopsies are carried out in the hope that the pathologist will support or rule out a clinical diagnosis of lupus erythematosus. I have not been able to get any pathologist, at least in New York, to commit himself to a diagnostic lesion in skin or muscle associated with lupus erythematosus. If the change Dr. Lowman reports is diagnostic, it would be extremely important, especially since it could be found in the skeletal muscle which could be subjected to biopsy.

We found no strict correlation between muscle and vascular changes.

Dr. J. F. Rinehart (San Francisco, Calif.): It is an important and solid observation that these lesions have been found in nerves and muscles. However, it should be noted that such lesions are found all over the body. I am sure Dr. Lowman knows that they are widespread, but it should be made quite clear that this is so. As a matter of fact, I found them so widespread that last year, at the meeting in New York, I presented the idea that disseminated lupus is really a vascular disease. I have never been much impressed with "fibrinoid degeneration" as a specific lesion in the disease, and believe that most of it could be accounted for by widespread injury to small vessels, and that it represents to a large extent the escape of fibrin into tissues. Note that I say, most of it. There is some collagenous, necrosis, but the vasculitis is a dominant feature of this disease. Even in the lesion seen in the spleen, with concentric perivascular collars of collagen, there is also evidence of injury to the intima and media of the splenic vessels.

Dr. Charles Ragan (New York): The histological changes found in these diseases depend upon the stage in the course of the disease at which the section is made.

I mention this because we have one patient who, in 1939, had what appeared clinically to be typical lupus erythematosus disseminatus, who was in fact very ill with pericarditis.

* A Paper entitled "A Vascular Lesion Observed in Rheumatoid Arthritis" was given by Drs. J. J. Bunim, L. Sokoloff, and S. L. Wilens at the Annual Meeting of the American Rheumatism Association, June, 1950. A summary of the paper and the ensuing discussion has already appeared in this Journal (Annals of the Rheumatic Diseases, 1950, 9, 388.) 
By the time she died in 1948, there were no specific lesions of lupus present in a complete autopsy which was reviewed by Dr. Klemperer.

These lesions may be specific for lupus in the active phase, as Dr. Bunim has suggested, but $I$ think we must keep in mind that this is a dynamic disease and that it depends upon the stage at which the lesions are removed whether they may be regarded as specific or not.

Dr. Lowman: We did not wish to imply that this is by any means a diagnostic reaction. I am sure that it is a nonspecific reaction that occurs in many different conditions, and that it would be of no value in the diagnosis of lupus.

Secondly, we did not intend to imply that these changes occur solely in muscles or nerves; we investigated these particular tissues because of the clinical manifestations which we had seen, and because they had not previously been investigated.

\section{REFERENCES}

Clawson. B. J., Noble, J. F., and Lufkin, N. H. (1947). Arch. Path., 43, 579.

Goeckerman, W. H. (1923). J. Amer. med. Ass., 80, 542.

Klemperer, P., Pollack, A. D., and Baehr, G. (1941). Arch. Path., 32, 569.

Libman, E., and Sacks, B. (1924). Arch. intern. Med., 33, 701.

\section{Modifications Musculaires, Nerveuses et Synoviales dans le Lupus Érythémateux}

\section{RÉSUMÉ}

(1) A l'examen histologique des muscles de 15 cas de lupus la dégénérescence musculaire, légère ou modérée, fut constatée dans $73 \%$ des cas; des modifications similaires furent trouvées dans $37 \%$ des 30 témoins.

(2) Dans le lupus érythémateux la réaction vasculaire, qui est surtout veineuse, semble passer par trois phases: d'oedème, de réaction cellulaire et de sclérose. Ces modifications vasculaires dans les muscles et autour des nerfs dans le lupus sont identiques à celles que nous avons vues dans certains cas d'arthrite rhumatismale active. Il n'a pas été possible de déterminer le degré du rapport entre la dégénérescence musculo-nerveuse et les changes vasculaires et on ne peut pas dire si l'un est l'effet de l'autre ou bien si les deux phénomènes sont concomitants (simultanés) et dérivent d'une incitation commune. Les modifications vasculaires du tissu synovial étaient similaires à celles qu'on avait vues ailleurs. De plus, le stroma présentait de l'oedème initial suivi de la réaction fibroblastique aboutissant à la résolution de la fibrose. Seulement quelques cellules du revêtement synovial montraient de l'hyperplasie.

(3) La nature identique de la réaction vasculaire dans le lupus et de celle rencontrée dans l'arthrite rhumatismale active, ainsi que la similarité de cette réaction et de la réaction observée dans la périartérite noueuse est d'un grand intérêt et mérite des recherches ultérieures.

(4) Il n'a pas été possible de déterminer si les modifications que nous avons observées sont secondaires à une réaction produite par un facteur exogène ou bien si elles constituent le résultat d'une réaction hyperergique endogène.

\section{Alteraciones Musculares, Nerviosas y Sinoviales en el Lupus Eritematoso}

\section{RESUMEN}

(1) Al estudiar histológicamente los músculos de 15 casos de lupus se ha encontrado degeneración muscular, leve o moderada, en $73 \%$ de los casos; alteraciones similares fueron halladas en $37 \%$ de los testigos.

(2) En el lupus eritematoso la reacción vascular, principalmente venosa, parece transcurrir en tres fases: de edema, de reacción celular y de esclerosis. Estas alteraciones vasculares en los músculos y alrededor de los nervios son idénticas a las que hemos visto en ciertos casos de artritis reumatoide activa. No pudimos determinar el grado de relación entre la degeneración músculonerviosa y las alteraciones vasculares y no se puede decir si el uno es la consecuencia del otro o si ambos fenómenos son concomitantes (simultáneos) y proceden de un estímulo común. Las alteraciones vasculares del tejido sinovial se parecían a las que hemos visto en otra parte. Además, el estroma presentaba edema inicial, seguida de la reacción fibroblástica y luego de la resolución de la fibrosis. Sólo algunas células de revestimiento sinovial presentaban hiperplasia.

(3) La naturaleza idéntica de la reacción vascular en el lupus y de la reacción encontrada en la artritis reumatoide activa, así como la similitud con la reacción observada en la periarteritis nodosa da mucho que pensar y merece estudios ulteriores.

(4) No se pudo determinar si las alteraciones observadas resultan de una reacción producida por un factor exógeno o si constituyen el resultado de una reacción hiperérgica endógena. 